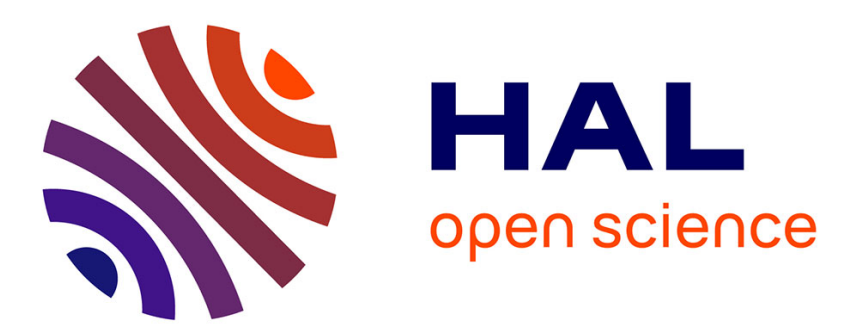

\title{
Peace without money, war without Americans. Can European strategy cope?
}

Delphine Deschaux-Beaume Deschaux-Dutard

\section{To cite this version:}

Delphine Deschaux-Beaume Deschaux-Dutard. Peace without money, war without Americans. Can European strategy cope?. European Security, 2017, pp.151-152. 10.1080/09662839.2016.1260006 . hal-01795191

\section{HAL Id: hal-01795191 \\ https://hal.univ-grenoble-alpes.fr/hal-01795191}

Submitted on 6 Jun 2018

HAL is a multi-disciplinary open access archive for the deposit and dissemination of scientific research documents, whether they are published or not. The documents may come from teaching and research institutions in France or abroad, or from public or private research centers.
L'archive ouverte pluridisciplinaire HAL, est destinée au dépôt et à la diffusion de documents scientifiques de niveau recherche, publiés ou non, émanant des établissements d'enseignement et de recherche français ou étrangers, des laboratoires publics ou privés. 


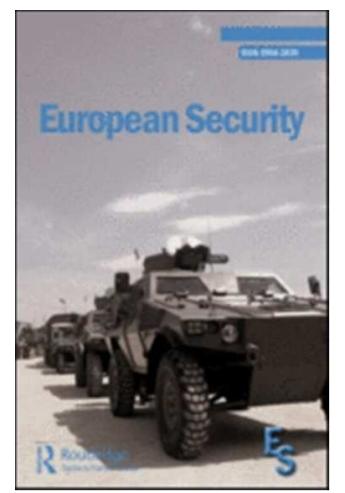

Sven Biscop, Peace without money, war without Americans. Can European Strategy cope ? London, Ashgate, 2015, 102 pages, $£ 18.31$. ISBN 9781472442918.

\begin{tabular}{|r|l|}
\hline Journal: & European Security \\
\hline Manuscript ID & Draft \\
\hline Manuscript Type: & Book Review \\
\hline Keywords: & \\
\hline & \\
\hline
\end{tabular}

SCHOLARONE ${ }^{m}$

Manuscripts 


\section{Sven Biscop, Peace without money, war without Americans. Can European} Strategy cope? London, Ashgate, 2015, 102 pages, £18.31. ISBN 9781472442918.

In a context of crisis in the Middle East (Syria, Yemen...), of tensions in the East (Ukraine) and migration crisis, the EU's external action is being put under considerable pressure. Thus reflecting on the question of the EU's strategy is not only interesting, but necessary, as the European Security Strategy (ESS) from 2003 has been reviewed and turned into a Global Strategy -"Shared vision, common action. A stronger Europe" presented by the High Representative Federica Mogherini at the European Council on June $28^{\text {th }} 2016$. The aim of Seven Biscop's latest book Peace without money, war without Americans is to help define what this European strategy should be. This latest opus proposes an interesting extension of his previous book and of an article published in International Affairs in $2013^{1}$.

The book starts with this sharp assessment: the EU is currently faced with the reorientation (or pivot) of the American strategy towards Asia and autonomy is thus forced upon Europe (p.xi). Therefore the EU is facing a double challenge as heralded in the title of the book: Europe not only needs to become able to use force when necessary against a context of restricted defence expenditures for most EU countries, but also has to be able to act militarily without being backed up by American military support. The key element of the argumentation is to exhort the EU to take advantage of the US pivot in order to define a clear and substantial strategy, thus enabling Europe to act as a real collective strategic player on the international security stage.

This short and effective book (102 pages) is divided into four parts: a prologue (bearing the suggestive title of "Snow White and the seven fallacies", Snow White representing the EU), and three chapters. The main thesis developed in the book is the following : faced with major strategic challenges, the EU needs more than ever to act collectively on the international security stage and needs a real grand strategy in order to fulfill this need ("a strategic actor requires a strategy", p. 31). The author underlines that the EU already has the platform to act and masters important economic, diplomatic and military means. But what is still missing is a consistent strategy to define what to do, and with what priorities and instruments, when Europe's interests are jeopardized. Hence most of the EU member states keep thinking in terms of national interests instead of on a collective European level. The example of the military intervention in Libya in 2011 is striking on this matter: not only could the EU not intervene on a collective European basis but the member states which participated under the British and French leadership had to rely on NATO's assets. Thus Sven Biscop raises the question whether the EU can cope in a context of enormous challenges, not only in the Middle East but also in the East (Ukraine) and with low military budgets.

To answer this question, the author starts with a prologue listing the seven fallacies preventing the EU from being the collective actor that it could be, considering the military tools and units and policy processes Europe masters especially through CSDP. Thus not only the national strategic reflex but also the lack of political will and of strategic thinking at EU level, and the misreprentation still going on about the relationship between the EU and NATO ("the CSDP and NATO are not two different castles [...] they are but wings of one and the same castle that defends the shire as a whole", p. 8) among others constitute important impediments.

\footnotetext{
${ }^{1}$ Sven Biscop, “Peace without money, war without Americans: challenges for European strategy”, International Affairs, Volume 89, Issue 5, September 2013 , pp. 1125-1142.
} 
These impediments prevent the EU from playing the global strategic role it could and will have to play in the near future, as the United States has started to show quite clearly that they would not get involved in the settlement of security crises in Europe's neighborhood unless forced to do it (see the example of Libya or Ukraine lately).

The three following chapters aim at demonstrating how these impediments can be overcome. Chapter 1 focusses on the need for strategy at the European level by clearly identifying what should be expected : a European strategy which would be effective not only relies on the affirmation of European core values, but also aims at setting priority objectives and pointing out the instruments and means to achieve them. As Biscop states, answering the strategic challenge is crucial as it comes down to own question: "the option is to act together or not to act at all" (p. 41); as the member states can no more imagine to overcome individually the many security challenges surrounding them. Chapter 2 proposes an in-depth analysis of how the ENP failed to stabilize the EU's neighborhood and proposes interesting arguments to reform it and make it effective, by differencing clearly the strategic needs in the southern neighborhood and in the eastern neighborhood. Finally, chapter 3 assesses the state of European defence capabilities and shows that the EU has important means but keeps jeopardizing their efficiency by cultivating competition with NATO. On the contrary Biscop advocates for the use of both NATO and CSDP as tools to back up a well-articulated EU strategy. Strategy won't promise success but at least it will enable the EU to act autonomously by being aware of its interests and the instruments to defend them (p. 92).

The book is a must-read for anyone who is interested by the subject of European security and defence policy and particularly for European political leaders, as it offers convincing arguments expressed in a fluid and vivid writing style.

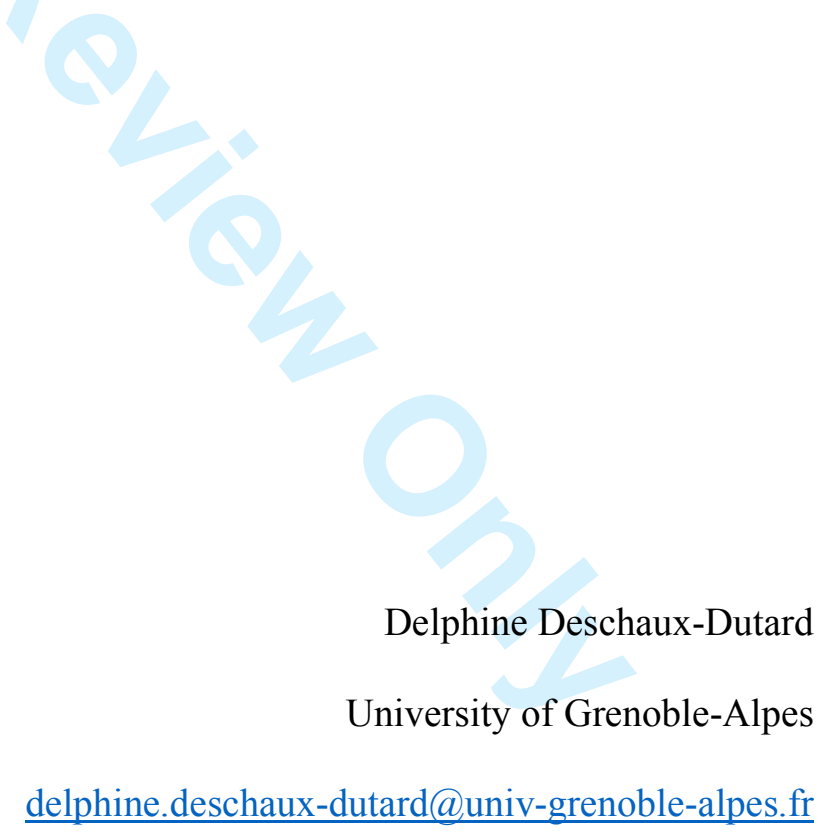

URL: http://mc.manuscriptcentral.com/feus Email: jocelyn.mawdsley@newcastle.ac.uk; l.chappell@surrey.ac.uk 